\section{The Inimitable}

\section{Ruth Baldwin}

\section{Anatomy of a Collector and a Library}

MARY MARSHALL

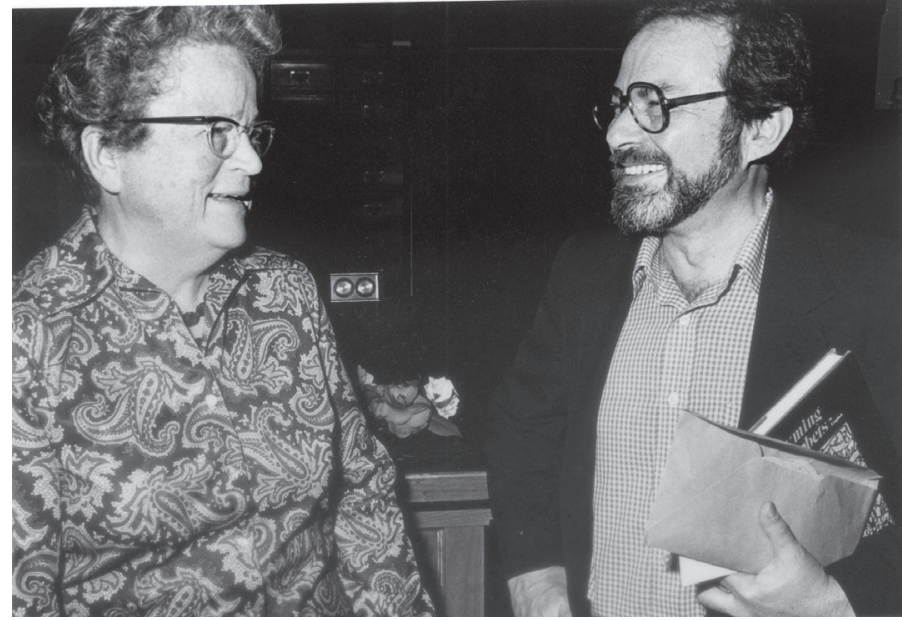

Maurice Sendak, pictured here with Ruth Baldwin, visited the Baldwin Library on February 10, 1982, shortly before the official dedication on March 27, 1982. Photo courtesy of the Baldwin Library.

In addition to reading the Baldwin papers, I also interviewed University of Florida staff and faculty members who knew Baldwin, including Sam Gowan, who was associate director of Collections and Services of the University of Florida, and Rita Smith, curator of the Baldwin Library, University of Florida. I also listened to a taped interview of Dr. Wofford Baldwin, Baldwin's uncle, conducted by Smith. The more I learned about Ruth Baldwin, the more fascinated I became - not with just her book collection, but also with her life.

Baldwin's correspondence and her diaries (which she kept her entire life) and other papers housed in the Baldwin Library give a glimpse of her interests and her philosophy about books and libraries from her earliest years until just days before her death. These materials also depict a social history of the time period when she lived, particularly those years between World War II and the late 1970s.

Her earliest diary is labeled 1917 to 1944. Although these earliest entries are written in pencil in a mature hand, indicating she did not write them as a young child, the entries from 1920 to 1928 are typed and are clearly her earliest memories of her childhood. Most are simply a few words in length and the ideas behind them are not always clear until one has read much more about her life.

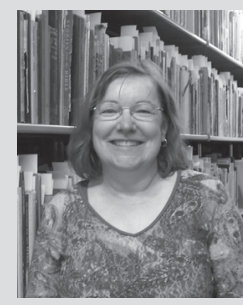

Mary Marshall is Assistant Director and Head of Children's Services at the Addison (IL) Public Library. She has given presentations and written about children's services, rare books, and Jane Austen. She was the 2007 Bechtel Fellowship winner. dream—she kept everything: diaries, letters, correspondence, invoices, lists of purchases, and books sold. The archives consist of 8.5 linear feet, contained in fifteen boxes. 
An example from her diary, 1920 to 1923, includes a typed summary of thoughts. At a poetry reading by Amy Lowell in Baltimore, Baldwin said aloud to her mother, "Won't the lady sometime stop?"

\section{Baldwin's Family}

Baldwin's father Thomas Whitfield Baldwin, born January 28, 1890, in South Carolina, was a world-renowned Shakespearean scholar. Much of the time during his daughter's childhood, college years, and early career, he was a professor at the University of Illinois (1923 to 1958). He had a tremendous influence on her life, and Baldwin was always striving for his acceptance-not an easy task. He was also Baldwin's model for book collecting. His collection was one of the finest of books that Shakespeare might have read.

Thomas Baldwin married Elisabeth (Regina Elisabeth Petrich) on December 20, 1917 in New Concord, Ohio. She was born August 19, 1890 in California, where she grew up. She attended medical school in Philadelphia for one year, but left to teach biology. After her marriage, Elisabeth was a housewife, mother, active volunteer, and assistant to her husband, typing his thesis and searching for books for his collection. Much of what we know about Ruth is through Elisabeth Baldwin's correspondence with her daughter. Elisabeth began Ruth's book collecting with a thirty-fifth birthday gift of a collection of chapbooks that she purchased in England in 1953. Elisabeth writes to her daughter on the occasion: "Last week papa \& I found a bunch of children's books-very early, at McLeish's. I was sure you would like them as they are really hard to come by now, so had Mr. McLeish send them to you. They are a birthday present—a bit late."

\section{Education and Professional Life}

Baldwin was quite precocious, and because of health problems, she was tutored at home until she entered school in 1926 as a fourth-grade student in Urbana, Illinois. In September 1935, she enrolled at the University of Illinois as a freshman, but the next year, she transferred to and later graduated from Muskingum College, New Concord, Ohio.

Baldwin's first mention of the possibility of being a librarian was in a letter to her parents, dated January 20, 1937, where she mentions the idea of "librarying" as a career. In 1939, she entered the University of Illinois to complete a bachelor's in library science, which she received in June 1940. Over the next fifteen years, she completed a master's (1945) and a PhD (1955) in library science at the University of Illinois.

Her professional life took her from South Dakota to Ohio to California to Louisiana, and finally to Florida. As with most people, she had complaints some days about her job. While at her first job as assistant librarian at Huron College in Huron, South Dakota (1940 to 1942), she wrote to her mother, "Furthermore at this stage I am about fed up on the library profession-here at least it is always and everlasting telling kids to 'shut up' and if I have to ask anybody else to please be quiet as their classmates are trying to study I will go mad."
Baldwin's real career interests, however, lie in teaching. In 1946, she was offered a teaching position at the San Jose (Calif.) State College Library School, where, she enjoyed the experience and her students. After three academic years at San Jose, Baldwin began the PhD program in Library Science at the University of Illinois, but she left after a year for a position at the University of Southern California's Library School. While there, she began a lifelong friendship with one of her students, Martha Peters, who described Baldwin as "an excellent teacher."

Baldwin completed her $\mathrm{PhD}$ at Illinois in 1955 and began to search for a permanent faculty position. In her attempts to obtain employment, she experiences job discrimination, not unusual for the time. In letters to her mother, she notes these problems: "They [Syracuse] are interested in a man only." Finally, she received her appointment (January 1956-77) to Louisiana State University, teaching library management, not children's literature as one would expect. She remained there until retiring and receiving an appointment in 1977 as Librarian and Curator of Children's Literature at the University of Florida. She retired there as University Librarian Emeritus in 1988.

In her diaries and letters, she also writes about her professional involvement: attending conferences and meetings, including a computer conference in 1957. In 1972, her alphabet book, 100 Nineteenth-Century Rhyming Alphabets in English, is published.

\section{Historical Notes in Her Diaries}

Because of Ruth's detailed records of her life, she also provides a social history of her times. In her letters and diaries, she wrote in detail about the movies, concerts, and plays she attended, the food she ate, the music she listened to, the clothing she wore, the purchase of her home and obtaining a mortgage, the decorating of her house, and the items she purchased-including a telephone, clock radio, digital clock, television, color television, new cars, and many more details of her everyday life. Ruth also records national events: the number of her college classmates who were killed during World War II, rationing, presidential elections, hurricanes, FDR's death, the assassination of John F. Kennedy, man on the moon, segregation, and the Ku Klux Klan, among others.

One of the more interesting entries was her recordings of atomic bomb tests. In her diary, she writes on March 17, 1952: "Saw flash of light at 5:20 a.m. while listening to A bomb explosion on radio." The same day, she writes to her mother that she set her alarm to watch the sky for the atomic bomb: "Then I lay and watched the sky as the seconds were counted off and as the newscaster said there it goes, a great light flashed across the sky."

\section{Reading}

For a person who recorded such details as the mileage on her odometer and the amount she paid for a piece of fabric, Ruth makes fairly few references in her diaries or letters to books she read. Her first reference to her reading was in a diary entry for July 1925 when she notes her reading of a "fairy story book." Her 
next reading reference is not until September 1929, when she records that she is reading Tarzan in school. Ruth's only other entries about her reading occur between 1946 and 1952, when she notes on ten occasions what she is reading, the majority of them popular books of the time, including Willa Cather's Sapphira and the Slave Girl and Betty MacDonald's Anybody Can Do Anything. Sam Gowan, who knew her well, believed that she did not read very much, an opinion shared by Rita Smith.

\section{Book Collection}

Ruth Baldwin might have been addicted to acquiring books, as Sam Gowan noted: "Ruth was conscious of her own neurosis, but couldn't control it. She bought books to accumulate not read." Ruth appeared to be a bibliomaniac rather than a bibliophile. She did not begin her obsession with books until receiving her thirtyfifth birthday gift from her parents. In a September 25, 1953, entry in her diary, Elisabeth notes the purchase: "Tom was of the opinion it might make a suitable birthday present for Ruth."

During the rest of her year in London, Elisabeth records sending another three hundred to four hundred chapbooks to Ruth. She writes to her daughter from England, on December 18, 1953: "This going after children's books could get me: I find it most fascinating." Ruth responds to her mother's letter about this first gift: "I'm perishing to see the books (I received your letter this morning.)" In her diary, October 16, 1953, she writes, " 2 packages 40 children's books from folks-wonderful belated birthday present."

In an unpublished memoir, Ruth writes about the philosophy of her collection:

\footnotetext{
"Even today libraries collecting children's literature have the Newbery and Caldecott Prize winning books and the classics and a few other notable books, but most students studying these books know that neither they nor their friends ever read them as children.... If books are a part of one's life one cannot have lived very long before the search begins for something read or heard in one's childhood."
}

The focus of her collection, particularly the twentieth-century portion, is on what children read and not necessarily what was found in a library. "My motto--the books that children read--is often not the books libraries would have for them ... [so] I also collect for my library as many Little Golden Books, Tell a Tale, Weekly Readers as I can-the kinds of books not found in libraries but found in department and grocery stores or subscribed to through the schools" Ruth did not begin purchasing twentieth-century children's books for her collection until she came to the University of Florida. Her collection is also significant because of its condition. Most collectors strive to collect the finest copy available. Ruth's philosophy was just the opposite:

\footnotetext{
"I do not always keep the best copy. I keep the inscribed and labeled one-the one used by children. A mint copy tells me nothing of this book. . . . As it is I have many books in my library ... not known to exist at all."
}

Ruth's methods of collecting changed over the years: "But all good things come to an end and by 1973 I could no longer argue that traveling to the bookstores was a practical way to build a library. Universities had quit buying books and prices in bookstores had become too high to risk buying many duplicates." She began depending on catalogs for purchases. In the summer of 1972, she notes that "supported by a gift from my father I made my largest by far single purchase, American children's books before 1821, from Ben Tighe." She also is aware of her own obsessions with purchasing books: "During my buying years I passed up many a precious book no doubt and I missed out on catalogues that were stopped even before I got them. I had almost a fetttish [sic] with catalogs."

Ruth's friend Margaret Peters writes about her Saturday yard sale excursions with Ruth in Gainesville: “These excursions were planned \& mapped with a military precision \& were much fun because we always came home with lots of goodies." In another letter to Rita Smith about her memories of Ruth, Margaret again refers to the yard sales, "She was an avid seeker of yard sales and flea markets. The Friday edition of the local paper was thoroughly examined and a careful battle plan worked out. She usually left around 7:00 A.M. . . . . Her memory and knowledge of the collection was phenomenal. Her search was organized and systematic." Sam Gowan saw Ruth's purchasing habits in a different light. He argued that she couldn't admit that she had a compulsion for garage sales: "She would sweat with fear that while she was at one garage sale, some one would be buying the gems at another. She would drive herself into a frenzy, a state of nervous exhaustion every Saturday."

Not surprisingly, Ruth's collection also contained family copies of titles. I was examining The Birds' Christmas Carol by Kate Douglas Wiggin because I owned a copy, and I discovered in the Baldwin copy an inscription to Ruth's mother:"Merry Christmas/To Elizabeth [should be Elisabeth] Petrich [her maiden name]/from Beulah Brown." Ruth noted that her father had owned, as a young boy, Children's Edition of Touching Incidents and Remarkable Answers to Prayer. When I examined the copies the library owned, I found one inscribed by him: “T.W. Baldwin's book.”

\section{Finances and Book Purchases}

In her diaries and letters, Ruth makes numerous mentions of her finances. Her earnings as a librarian varied from $\$ 1,000$ for her first job in 1940 in Heron, Ohio to $\$ 14,000$ when she came to the University of Florida. Surprisingly, with these salaries, she is able to buy a house $(\$ 10,800$ in 1957$)$, travel, and build an important collection of children's books.

Ruth kept extensive correspondence with the many booksellers. Mrs. P. Lemming of Andrew Boyle Booksellers describes Ruth's purchases:

"She also much preferred a book with an inscription on the end papers or title page, and would always duplicate a copy she already had for a nice inscription (e.g., 'To dear little Willy for gaining a prize at school, from his Papa')...." 
Justin Schiller, one of the most important children's booksellers, had been a competitor of Ruth's in purchasing children's books. In his recollections of Ruth, he writes:

"I do know that she was very competitive, and would try especially hard to secure something important if it were not in the Shaw Collection at Tallahassee (and should have been there!) . . . I believe, that when she considered something expensive-as in the only known set of The Poetic Garland which she acquired from us-she negotiated to pay for it over a long time period...."

Ruth paid Schiller \$10,000 for Poetic Garland, published in 1808 by John Harris.

In addition to purchasing from bookseller's shops and catalogs and yard sales, Ruth also bought from resale shops: "I visited my sister in Cleveland and found several hundred books in such places as the Goodwill and the Salvation Army bookstores, so I remained hooked."

Ruth kept notebooks and receipts for her book purchases. In notes for a possible memoir, she wrote, "In building my library my first catalogs were my fathers.... As these books were ordered by my father and paid only indirectly by me I have no record of them." Not including these expenditures (1953-78), she spent $\$ 158,847$ on books. The final total would be even more, because this total is only for books that she paid for by check. Ruth lists additional purchases with "cash" next to them, and we know she also purchased books at yard sales and flea markets where she paid cash.

Clearly Ruth was spending a great deal of money on her collecting for such a limited income. She was able to do this because of occasional monetary gifts from her parents, especially her portion of the proceeds from the sale of her father's book collection to the University of Illinois. This gift was the first large fund that she ever had to use for her collection. In 1972-73, she used these funds to purchase an important collection of American children's books from Benjamin Tighe for \$20,000: 433 Welch titles of American Children's books before 1821 and a group of 152 alphabet books, before 1890. Even with these additional funds, she paid Tighe for the collection in installments.

Her purchasing begins to taper off in the mid- to late-1970s as she begins to consider what to do with her enormous collection. As early as 1973, there are indications that she is thinking about the future of this collection. She writes to bookseller Ken Leach: "And I just decided in earnest to retire three years this June and quit buying, and you turn into a juvenile books store!"

The other method she discovers to add to her book purchasing funds is to sell her duplicates. Because it was not unusual for her to purchase entire shelves of books from dealers, she frequently had duplicates. She writes "I discovered that I could sell my duplicates... . These sales made it possible for me to buy other volumes suited to my library. ..." She kept detailed lists of these sales also, and from 1964 to 1975, she sold books totaling \$65,672 to sixteen universities. Another means of selling her duplicates was through a "bookstore" in the Baldwin Library. As Gowan notes, "She was running a bookstore out of the Baldwin, unbeknownst to anyone. She was selling her duplicates. She was a 'scoop' buyer, buying whole walls. This is why she had duplicates."

\section{The Baldwin Library}

Ruth realized that her collection would eventually need an institution to house it. Her home was filled with books to the point that she was forced to construct an addition, with extra support, for the books. About the time she began to outgrow this space, she had the opportunity to bring the collection to the University of Florida with herself as curator. On April 27, 1975, Ruth attended a lecture at a conference given by Joy Anderson, a University of Florida English professor and author. When Joy found out about Ruth's collection, she asked for a tour of Ruth's books on April 29. Joy Anderson returned to the University of Florida and discussed Ruth's collection with Library Director Gus Harrer. Harrer, a pilot, flew Joy and several other university staff and officials to Louisiana to tour Ruth's collection.

In July, Ruth visited the University of Florida to explore the possibility of donating her collection. She wrote to The Robins, about this experience, "Back in July, Gus Harrer, the librarian, the vice president, the head of the English department and several others flew to Baton Rouge to see my library, and I had promised to go over and visit them with the idea of moving there. It was a nice experience-I hadn't been wooed that much in this life. . . I I do not know that the university as a whole is strong enough to support this project. . . It is a big decision as it is so final. I can't move 40,000 books twice in this life."

As Sam Gowan noted, the 1970s was a time when academic libraries were expanding their collections: "In the 70s, print libraries were really important. If a University was developing a program, they had to find a book collection to support the program. This was the importance of acquiring the Baldwin collection [to support the Children's Literature program]." Gowan was involved in negotiating to bring Ruth and her collection to the University of Florida. On August 19, 1976, G. A. Harrer, director of the libraries, sent Ruth a proposal for her collection and her employment. She was offered the position of librarian and curator of the Children's Literature Collection at a salary of $\$ 14,000$ beginning July 1,1977 . In a letter to Harrer, Ruth apologized for an error in the size of her collection, the collection being 32,500 volumes rather than the 35,000 she had claimed. Ruth explained that even without these extra volumes, she "payed [sic] at least $\$ 130,000$ for [the collection] and which cannot be replaced at any cost."

The difference in size of the collection does not appear to be a problem, and Ruth sends her acceptance of the terms on October 27 , 1976. The collection was moved from Ruth's home to the University of Florida beginning April 24, 1977, and Ruth followed.

Catherine Dunlop was Ruth's first assistant, followed by Wendy Scott (leaves in November 1982), and finally Rita Smith (who begins June 26, 1983, as noted in Ruth's diary). Ruth was very 
popular with her staff. According to Sam Gowan, "Most of the people who worked for her, loved her. She was very kind to them."

Space soon became an issue in Library East, where the Baldwin library is housed. When Ruth brought her collection to the library, there were 32,500 volumes; on the tenth anniversary, there were more than one hundred thousand volumes. Robert Singerman, acting head, Department of Special Collections, noted:

\footnotetext{
"The accumulation of fairly modern juvenilia at yard sales or from discarded books donated by the public schools accounts for much of the Baldwin Library's growth. For a variety of reasons, among them Dr. Baldwin's imminent retirement and library-wide concerns over insect infestation, these sources are no longer viable. During the past three years, a comic book collection and an almanac collection of almost 4,000 volumes [Cynthia Baldwin's] have been added to the Baldwin Library.”
}

\section{Last Months and Death}

In her diaries for the last few months of her life, Ruth noted health problems and medical appointments, not unusual for her because her diaries all have similar references. Yet, in the same time period, she still enjoyed the outdoors: a swim on October 29, a hike on November 7, a two-mile hike on the 8th, a three-mile hike on the 11th. Ruth continued her collecting too, but not at the same level as previously. She found some children's books at yard sales on November 18; visited flea markets in the Ocala, McIntosh, and Micanopy areas on November 24, added to her elephant collection on December 19 in Micanopy, purchased an elephant filled with powder and two turquoise elephants on December 26 and 27, and made unspecified purchases in the Ocala and Green Cove Springs areas. The December 27 entry was the last in her diary.

On January 5, 1990, she died at Shands Hospital in Gainesville. Sam Gowan noted, "Cynthia spread ashes every place Ruth loved. I think she put some in the corner of the Baldwin Library. It was a relief that her ashes were spread so widely so that she won't come back together and get me."

\section{Future of the Baldwin Library}

Even with the death of Ruth Baldwin, the story of the Baldwin Library has not ended. In February 2007, a new addition of 2,800 illustrated American children's books, dating from 18072003, formed and donated by Dr. Robert L. Egolf, arrived at the Baldwin Library. Egolf created his book collection to diversify his investment portfolio, on the recommendation of his financial advisor. When asked why he chose children's books, Egolf recalled that he had rabbit bookends that cried out for children's books. In excellent condition, Egolf's collection, consisting of the high spots of illustrated American children's books, has an estimated worth of more than a half million dollars.

I was working on my fellowship when the Egolf books arrived. Because of my many years of experience working with rare books, then-curator Rita Smith gave me the opportunity to explore the collection. Those of us in the Baldwin Library the day the collection arrived surely felt the same excitement that the University of Florida's Smather's Library staff felt almost thirty years before when Ruth Baldwin brought her magnificent collection to the University of Florida.

On my last day at the Baldwin Library, I assisted Smith in creating a display for the reception honoring Egolf's donation. The cataloging of the Egolf collection was completed in 2011, and future scholars now have the opportunity to research these new additions to the Baldwin Library. $\&$.

\section{References}

1. Carla Summers, A Guide to the Papers of Louise Seman Bechtel, August 2004. www.library.ufl.edu/spec/ manuscript/guides/bechtel.htm

2. Correspondence, letters, unpublished manuscripts, and unpublished memoir references are from the Ruth M. Baldwin Papers.

3. Ruth M. Baldwin, Diary 1920-1923, no date, Ruth M. Baldwin Papers.

4. Southern Illinoisan, "Thomas Whitfield Baldwin, 93, dies," January 15, 1984.

5. Dr. Wofford Baldwin, interview by Rita J. Smith and Bernard F. McTigue, February 9, 1993, transcript, Ruth M. Baldwin Papers.

6. Elisabeth Baldwin to Ruth M. Baldwin, October 7, 1953, Ruth M. Baldwin Papers.

7. Ruth M. Baldwin to Thomas Baldwin and Elisabeth Baldwin, January 20, 1937, Ruth M. Baldwin Papers.

8. Ruth M. Baldwin to Elisabeth Baldwin, March 1, 1941, Ruth M. Baldwin Papers.

9. Ruth M. Baldwin to Elisabeth Baldwin, December 22, 1951, Ruth M. Baldwin Papers.

10. Martha Peters to Cynthia Baldwin, January 21, 1990, Ruth M. Baldwin Papers.

11. Ruth M. Baldwin to Elisabeth Baldwin, June 10, 1955, Ruth M. Baldwin Papers.

12. Ruth M. Baldwin, 100 Nineteenth-Century Rhyming Alphabets in English, from the Library of Ruth M. Baldwin (Carbondale, IL: Southern Illinois University Press, 1972).

13. Ruth M. Baldwin, Diary 1952, March 17, 1952, Ruth M. Baldwin Papers.

14. Ruth M. Baldwin to Elisabeth Baldwin, March 17, 1952, Ruth M. Baldwin Papers.

15. Ruth M. Baldwin, Diary 1925, July 1925, Ruth M. Baldwin Papers.

16. Ruth M. Baldwin, Diary 1929, September 1929, Ruth M. Baldwin Papers.

17. Gowan, personal interview.

18. Rita Smith, interview with the author, February 2007.

19. Gowan, personal interview.

20. Elisabeth Baldwin, Diary, September 25, 1953, Ruth M. Baldwin Papers.

21. Elisabeth Baldwin to Ruth M. Baldwin, December 18, 1953, 
Ruth M. Baldwin Papers.

22. Ruth M. Baldwin to Elisabeth Baldwin, October 10, 1953, Ruth M. Baldwin Papers.

23. Ruth M. Baldwin, Diary, October 16, 1953, Ruth M. Baldwin Papers.

24. Ruth M. Baldwin, unpublished memoir, no date, Ruth M. Baldwin Papers.

25. Ibid.

26. Ibid.

27. Ibid.

28. Ibid.

29. Ibid.

30. Margaret Peters to Cynthia Baldwin, January 21, 1990, Ruth M. Baldwin Papers.

31. Margaret Peters to Rita Smith, November 19, 1993, Ruth M. Baldwin Papers.

32. Gowan, personal interview.

33. Kate Douglas Wiggin, The Bird's Christmas Carol (Boston: Houghton Mifflin, 1888).

34. S. B. Shaw, Children's Edition of Touching Incidents and Remarkable Answers to Prayer (Grand Rapids, MI, S.B. Shaw, 1896).

35. Mrs. P. Lemming to Rita Smith, June 15, 1992, Ruth M. Baldwin Papers.

36. Justin Schiller to Rita Smith, June 22, 1992, Ruth M. Baldwin Papers.
37. John Harris, Poetic Garland (London: J. Harris, 1808).

38. Ruth M. Baldwin, unpublished memoir.

39. Ibid.

40. Gowan, personal interview.

41. Ruth M. Baldwin, unpublished notes, no date, Ruth M. Baldwin Papers.

42. Ruth M. Baldwin to Ken Leach, October 10, 1973, Ruth M. Baldwin Papers.

43. Ruth Baldwin, "The Baldwin Library,” Horn Book, August 1982, 462-63.

44. Gowan, personal interview.

45. Ruth M. Baldwin, circle letter to a group of friends, October 27, 1975, Ruth M. Baldwin Papers.

46. Gowan, personal interview.

47. Ruth M. Baldwin to G.A. Harrer, September 9, 1976, Ruth M. Baldwin Papers.

48. Gowan, personal interview.

49. Robert Singerman, "Report of the Department of Special Collections for 1985-87 Submitted to the Director of the Libraries," February 26, 1988, Ruth M. Baldwin Papers.

50. Ruth M. Baldwin. Diary 1989, Ruth M. Baldwin Papers.

51. Gowan, personal interview.

52. Rita Smith, personal interview with the author, February 2007.

\section{WAR BOY TO WAR HORSE, continued from page 9}

As one theatre goer in London told me, "War Horse is the greatest anthem to peace I've ever seen on a stage." There is no more appropriate place for this story to be played at than in Berlin.

Then, as if the triumph of the play hasn't been enough, Kathy Kennedy, Steven Spielberg's producer, if you please, walks into the theatre in London with her daughter and sees the show. She's blown away, as everyone is. Within a week, Spielberg himself flies over to see it. Within a year he's making the film, which later garnered six Oscar nominations. The book is now in more than forty-five languages and sells really quite well these days, too. Kathy Kennedy and Steven Spielberg, two more helping hands.

How often since have I explored warfare and a longing for peace in my novels-Private Peaceful and the Butterfly Lion again set in the First World War. The Amazing Story of Adolphus Tips, the story of two black G.I.'s who came to Britain, to Devon in 1943, to train and prepare for the D-Day landings, and their relationship with a Devon farming family, and a cat. The Elephant In The Garden-my tale about the bombing of Dresden. The
Mozart Question, which deals with the Holocaust and the Jewish musicians who were forced to play in the concentration camps, and the power of music to sustain us.

Shadow is set in the War in Afghanistan, of an Afghan family fleeing the country and trying to seek asylum in Britain. The Kites Are Flying is a story of hope, where there is seemingly little hope. Set now in Palestine and Israel, it is about children who fly kites of peace over walls, built to protect or imprison, depending on your point of view. There is desperate sadness and grieving in all these stories, but there is always hope too. That's so important not just for children but for us too.

So lecture over-you'll be glad to hear. Story time. This story I'm going to read to you is about conflict but it is also about a librarian, and also the power of books and stories to change lives. Actually in a way it's about people like you and like me, who have made it our life's work to pass on our love of stories and poems to children.

So this is for you. "I Believe In Unicorns." ¿ 